\title{
A fully validated microbiological assay to evaluate the potency of ceftriaxone sodium
}

\author{
Maria Luisa Manfio, Danielle Araújo Agarrayua', Jaison Carlosso Machado², \\ Cleber Alberto Schmidt ${ }^{3, *}$
}

\author{
${ }^{1}$ Pharmacy Course, Franciscano University Center, Santa Maria, Brazil, ${ }^{2}$ Faculty of Pharmacy, \\ Federal University of Rio Grande do Sul, Porto Alegre, Brazil, ${ }^{3}$ Department of Medicines, Faculty of Pharmacy, \\ Federal University of Bahia, Salvador, Brazil
}

\begin{abstract}
Ceftriaxone (CFTX) sodium is a third-generation, broad-spectrum cephalosporin that is resistant to betalactamases. An alternative bioassay for the assessment of the potency of this drug in pharmaceutical formulations has not been previously reported. Thus, this paper reports the development and full validation of a $3 \times 3$ agar diffusion bioassay using a cylinder-plate method to quantify CFTX sodium in pharmaceutical samples. The strain Staphylococcus aureus ATCC 6538P was used as the test microorganism, and the results of the proposed bioassay displayed high linearity, precision, accuracy, specificity and robustness. All potency results were statistically analyzed using an analysis of variance (ANOVA) and were found to be linear $(\mathrm{r}=0.99999)$ in the range of $16-64 \mu \mathrm{g} / \mathrm{mL}$, accurate $(100.5 \%)$, and precise [repeatability: relative standard deviation $(\mathrm{RSD})=1.4 \%$; intermediate precision: between-day $\mathrm{RSD}=2.1 \%$ and between-analyst $\mathrm{RSD}=2.5 \%$ ]. The specificity of the bioassay was determined by evaluating a degraded sample $\left(50{ }^{\circ} \mathrm{C}\right)$ at 0,24 and 48 hours as compared against the results from the pharmacopeial liquid chromatography method for CFTX. The results validated the proposed microbiological assay, which allows reliable quantitation of CFTX in pharmaceutical samples. Moreover, it is a useful, simple and low-cost alternative method for monitoring the quality of this medicine.
\end{abstract}

Uniterms: Ceftriaxone/agar diffusion assay. Ceftriaxone/quality control. Ceftriaxone/microbiological assay. Drugs/quality control.

A ceftriaxona sódica é uma cefalosporina de terceira geração de uso parenteral, com amplo espectro de atividade e resistente a $\beta$-lactamases. Este estudo apresenta o desenvolvimento e validação de um bioensaio por difusão em ágar usando o método de cilindros em placas para determinação da potência deste antibiótico. A validação desenvolvida apresentou bons resultados em termos de linearidade, precisão, exatidão, especificidade e robustez. Empregou-se o Staphylococcus aureus ATCC 6538P como micro-organismo teste. Os resultados dos ensaios foram tratados estatisticamente utilizando-se análise de variância (ANOVA). O método apresentou linearidade $(r=0,99999)$ na faixa de doses selecionada (16-64 $\mu \mathrm{g} / \mathrm{mL}$ ), precisão (repetibilidade: $\mathrm{DPR}=1,4 \%$; precisão intermediária: inter-dias $\mathrm{DPR}=2,1 \% \mathrm{e}$ inter-analistas: DPR $=2,5 \%$ ) e exatidão de $100,5 \%$. A especificidade do bioensaio foi avaliada através da análise comparativa, por cromatografia líquida de alta eficiência, de amostras degradadas a $50{ }^{\circ} \mathrm{C}$ nos tempos zero, 24 e $48 \mathrm{~h}$. Os resultados encontrados demonstraram a validade do bioensaio proposto, o qual permite a quantificação confiável de ceftriaxona sódica em produtos farmacêuticos comerciais. Por ser metodologia simples e de baixo custo constitui-se em alternativa para a análise de rotina do controle de qualidade de medicamentos.

Unitermos: Ceftriaxona/ensaio de difusão em ágar. Ceftriaxona/controle de qualidade. Ceftriaxona/ ensaio microbiológico. Fármacos/controle de qualidade.

"Correspondence: C. A. Schmidt. Departamento do Medicamento, Faculdade de Farmácia. Rua Barão do Jeremoabo, 147. Ondina, 40170-115 - Salvador - Bahia, Brasil. Phone: +55-71-3237-7635. E-mail: cleber.alberto@ufba.br; cas1375@gmail.com 


\section{INTRODUCTION}

Ceftriaxone (CFTX) sodium is a semisynthetic antibiotic that can effectively treat several types of bacterial infections. Unlike the other $3^{\text {rd }}$ generation cephalosporins, CFTX has a long plasma half-life, up to 4- to 10-times longer than the other antibiotics in this class (Neu et al., 1981; Stoeckel, 1981). This cephalosporin shows a broad spectrum against Gram-positive and Gramnegative bacteria, including enterobacteria, Haemophilus influenzae and Streptococcus pneumoniae (Rebuelto et al., 2002).

Regarding the official quality control of CFTX, as raw material or in pharmaceutical preparation, the pharmacopeias recommend employing reversed phase liquid chromatography (RP-HPLC) with UV detection and a mobile phase composed of water, phosphate buffer and acetonitrile (British Pharmacopoeia, 2009; European Pharmacopoeia, 2005; Japanese Pharmacopeia, 2006; United States Pharmacopeia, 2011).

Several alternative physicochemical methods to assay CFTX in pharmaceutical formulations are described in the literature, such as spectrophotometric methods (El-Walily et al., 2000; Al-Momani, 2001; Amim, Ragab, 2004; Sankar et al., 2006; Okoye et al., 2007; Adegoke, Quadri, 2012), flow injection analysis (FIA) with chemiluminescence detection (Yinhuan, Jiuru, 2006), spectrofluorometry (Shah et al., 2011), reversed-phase high-performance liquid chromatography (RP-HPLC) (Hecq et al., 2006; Jane et al., 2006; Tippa, Singh, 2010; Akl et al., 2011), high performance thin layer chromatography (HPTLC) (Eric-Jovanovic et al., 1998) and differential pulse polarography (DPP) (Sengün et al., 1985).

To assess the concentration of CFTX in biological matrices such as plasma, serum, cerebrospinal fluid and bile, several physicochemical methods have been reported, such as HPLC (Patel et al., 1981; Trautmann, Haefelfinger, 1981; Ascalone, Dal Bò, 1983; Bowman et al., 1984; Chan et al., 1986; Granich, Krogstad, 1987; Bompadre et al., 1998; Kohlhepp et al., 1998; Tsai et al., 1999; Nemutlu et al., 2009; Mcwhinney et al., 2010), spectrofluorometric assays (Omar et al., 2009), and capillary zone electrophoresis (CZE) (Quaglia et al., 1997). Microbiological techniques are used to evaluate the bioavailability of CFTX in biological fluids (Rebuelto et al., 2002; Ismail et al., 2005) and to study the susceptibility of several microorganisms to CFTX (Beskid et al., 1981; Eickhoff, Ehret, 1981; Baumgartner, Glauser, 1983; Emmerson et al., 1985; Dias et al., 1998).

The use of microbiological assays to evaluate the potency of CFTX in pharmaceutical formulations is uncommon. The literature reports only one method which uses a 5 point calibration curve with paper discs in a bilayer agar diffusion assay using Bacillus subtilis (ATCC 6633 ) as the test microorganism (Cantón et al., 1993). However, the original method was not validated and the quantification does not follow the procedure recommended for a $5 \times 1$ assay (Esteban et al., 1990).

Physicochemical techniques are recognized to be fast, precise and accurate in quantifying cephalosporin antibiotics. However, some disadvantages are inherent to these methods, as the interference of the excipients, tedious extraction steps and lack of selectivity complicate the performance (Ahmed et al., 2011; Adegoke et al., 2012). Furthermore, most of these procedures are not simple in the routine analyses, they require dedicated or sophisticated equipment and expensive reagents, which are often not available in quality control laboratories (ElWalily et al., 2000; Souza et al., 2006).

Alternative methods to evaluate the potency of antibiotics, such as the fully validated microbiological agar diffusion assay, are simple and operationally inexpensive. Furthermore, such bioassays are suitable for quality control laboratories that do not have specialized and sophisticated instruments (Souza et al., 2006; Schmidt et al., 2008,2009).

Therefore, the aim of the present study was to develop and validate a low-cost, simple, specific, accurate and reproducible microbiological agar diffusion assay using a cylinder-plate method and propose it as a useful alternative to the physicochemical methods described in the literature for quantitation of ceftriaxone sodium as raw material and injectable formulation.

\section{MATERIAL AND METHODS}

\section{Chemicals}

The ceftriaxone sodium reference standard from Brazilian Pharmacopeia (assigned purity $847.3 \mu \mathrm{g} / \mathrm{mg}$ ) and the sample were commercially obtained. The sample (batch 97728B) was within its shelf-life and claimed to contain $500 \mathrm{mg}$ of ceftriaxone sodium sterile powder for injection (Eurofarma, Brazil). All reagents used were analytical grade (Difco, USA; Merck, Germany). Ultrapure and bidistilled water were used in the experiments.

\section{Ceftriaxone sodium reference solution}

Ten milligrams of the ceftriaxone sodium reference standard was transferred into a $100 \mathrm{~mL}$ volumetric flask 
and dissolved in sterile phosphate buffer solution $\mathrm{pH} 7$ $\left[\mathrm{K}_{2} \mathrm{HPO}_{4} 1.36 \%(\mathrm{w} / \mathrm{v})\right.$ and $\left.\mathrm{KH}_{2} \mathrm{PO}_{4} 0.4 \%(\mathrm{w} / \mathrm{v})\right]$. Aliquots of this solution were diluted in the identical buffer yielding working solutions with final concentrations of 16, 32 and $64 \mu \mathrm{g} / \mathrm{mL}$ (S1, S2 and S3, respectively).

\section{Preparation of the sample solutions}

Five-hundred milligrams of the CFTX sample was transferred to a $250 \mathrm{~mL}$ volumetric flask and dissolved with sterile phosphate buffer solution $\mathrm{pH} 7$. Five milliliters of this solution were transferred to a $25 \mathrm{~mL}$ volumetric flask and dissolved to obtain a final concentration of $400 \mu \mathrm{g} / \mathrm{mL}$. Aliquots of this solution were further diluted in the identical buffer solution to obtain the concentrations of 16,32 and $64 \mu \mathrm{g} / \mathrm{mL}$ (T1, T2 and T3, respectively), which were tested against S1, S2 and S3.

\section{Microorganism and inoculum standardization}

The strain Staphylococcus aureus ATCC 6538P was selected as the test microorganism because of its susceptibility to ceftriaxone sodium, yielding sharply defined zones of growth inhibition, which allows more precise measurements. The culture of Staphylococcus aureus ATCC 6538P (INCQS - National Institute for Health Quality Control, Brazil), after reconstitution, were cultivated and maintained on Grove-Randall's 1 culture medium (Difco). The microorganism standardization was prepared according to the procedure described in the Brazilian and USP Pharmacopeias (Farmacopeia Brasileira, 2010; United States Pharmacopeia, 2011). Prior to use, the microorganism was grown in a slant medium (Grove-Randall's 1, for $24 \mathrm{~h}$ at $35 \pm 2{ }^{\circ} \mathrm{C}$ ). Using aseptic techniques, the growth was suspended in a $0.9 \%$ $\mathrm{NaCl}$ sterile solution and diluted to give a suspension with $25 \pm 2 \%$ turbidity (transmittance) at $580 \mathrm{~nm}$ using a $10 \mathrm{~mm}$ absorption cell, with $0.9 \% \mathrm{NaCl}$ sterile solution as blank. The Grove-Randall's 1 culture medium at $48{ }^{\circ} \mathrm{C}$ was inoculated with the standardized suspension at $1 \%$ $(\mathrm{v} / \mathrm{v})$ to compose the upper layer in the plate.

\section{Agar diffusion bioassay}

The bioassay followed the $3 \times 3$ parallel line design ( 3 doses of standard and 3 doses of sample in each plate), with 6 plates/assay, in accordance with the European and Brazilian Pharmacopoeias (European Pharmacopoeia, 2005; Farmacopeia Brasileira, 2010). For the base layer agar, $21 \mathrm{~mL}$ of Grove-Randall's 2 culture medium (Difco) in a $100 \times 20 \mathrm{~mm}$ Petri dish was used. After solidifying, $5 \mathrm{~mL}$ of inoculated Grove-Randall's 1 medium was poured onto the base layer. In each plate, 6 stainless steel cylinders $(8 \times 6 \times 10 \mathrm{~mm}-$ external diameter $\mathrm{x}$ internal diameter $\mathrm{x}$ height) were placed on the surface of the inoculated medium. Three alternated cylinders were filled with $150 \mu \mathrm{L}$ of reference solutions (S1, S2 and S3), and the other three cylinders were filled with the concentrations of the sample solutions (T1, T2 and T3) (Figure 1). The plates were incubated at $35 \pm 2{ }^{\circ} \mathrm{C}$ aerobically for $16 \mathrm{~h}$. The growth inhibition zone diameters $(\mathrm{mm})$ were carefully measured with an electronic caliper. All experiments were performed in a biological safety cabinet and the infected material was decontaminated before being discarded.

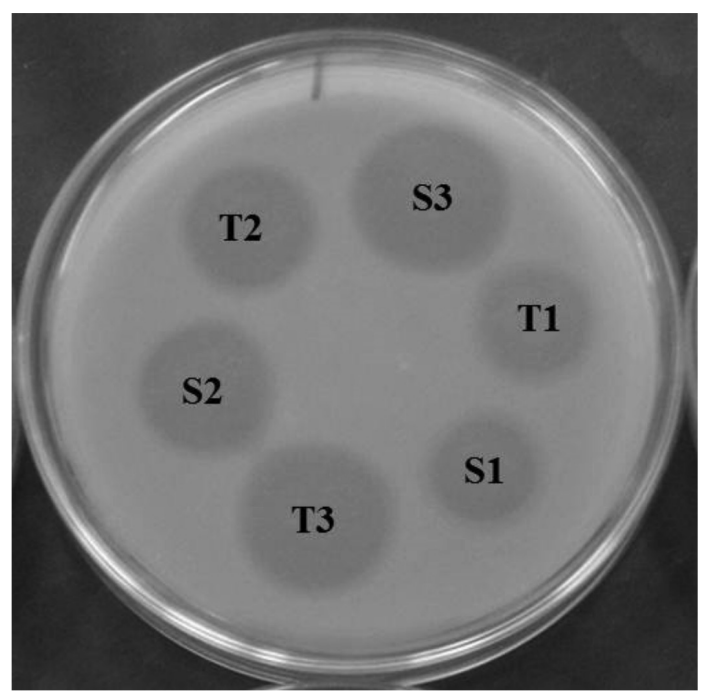

FIGURE 1 - CFTX potency evaluation by agar diffusion assay using the cylinder-plate method with a $3 \times 3$ experimental design. Zones of growth inhibition observed for doses 16, 32 and $64 \mu \mathrm{g} / \mathrm{ml}$ of the CFTX reference substance $(S 1, S 2, S 3)$ and sample $(T 1, T 2, T 3)$ using the strain $S$. aureus ATCC 6538P.

\section{HPLC}

In addition to the bioassay, the remaining CFTX after hydrolysis degradation was assessed by a LC method using the chromatographic conditions described in the USP monograph for CFTX sodium (United States Pharmacopeia 2011). Briefly, $20 \mu \mathrm{L}$ sample volumes were injected into a LC system (Shimadzu LC-10AD, Japan) equipped with a $270-\mathrm{nm}$ detector and a C18 column (4x $150 \mathrm{~mm}$ ). Each sample was run in triplicate. The mobile phase (water, acetonitrile, buffer solution $\mathrm{pH} 7$, buffer solution $\mathrm{pH} 5-552: 400: 44: 4)$ containing $0.32 \%$ of tetraheptylammonium bromide was used at a flow rate of $2 \mathrm{~mL} / \mathrm{min}$. 


\section{Calculations}

In all experiments, the CFTX potency was statistically calculated using the parallel-line model for a 3 $\mathrm{x} 3$ assay design. The regression, parallelism and linearity of the response were evaluated by an analysis of variance (ANOVA). To complement the statistical validation, the confidence interval (IC95) of each assay was considered (Farmacopeia Brasileira, 2010; Hewitt, 2003; European Pharmacopoeia, 2005; ICH, 2005; Schmidt et al., 2009).

\section{Validation of the method}

All experimental conditions of the proposed method were tested and adjusted prior to the validation to ensure the best assay conditions. The method was validated according the International Conference on Harmonization (ICH 2005) and USP guidelines 2011). The following operational characteristics were evaluated:

Range-Assessed by the selected doses for the calibration curve and confirmed by determination of the accuracy, precision and linearity of the method.

Linearity - Evaluated through 12 independent assays using linear regression analysis and calculated by a leastsquares method for three doses of the reference substance.

Precision - Assessed through the repeatability and intermediate precision and expressed as the relative standard deviation (RSD). The repeatability was examined by assaying 6 different test solutions of the CFTX sample against the reference standard. The assays were performed by the same analyst, under identical experimental conditions in one day (intraday). The intermediate precision was evaluated by performing the analysis in the same laboratory on 2 separate days (interday) with different analysts (between-analysts).

Accuracy - The test was repeated in three consecutive days. Three concentration levels, covering $80 \%$ to $120 \%$ of the selected range of 16,32 and $64 \mu \mathrm{g} / \mathrm{mL}$, were tested each day. Forty mg of CFTX was transferred to a $100 \mathrm{~mL}$ volumetric flask and dissolved in a phosphate buffer solution $\mathrm{pH} 7.0$ to obtain a stock solution with a concentration of $400 \mu \mathrm{g} / \mathrm{mL}$. The 3 concentration levels at $100 \%$ were prepared from aliquots of 1,2 and $4 \mathrm{~mL}$ of the stock solution transferred into $50 \mathrm{~mL}$ volumetric flasks and diluted with a phosphate buffer solution $\mathrm{pH} 7$ to give final concentrations of 16,32 and $64 \mu \mathrm{g} / \mathrm{mL}$, respectively. The doses at $80 \%$ nominal concentration were prepared from aliquots of $0.8,1.6$ and $3.2 \mathrm{~mL}$ of the stock solution transferred into $25 \mathrm{~mL}$ volumetric flasks to give final concentrations of $12.8,25.6$ and $51.2 \mu \mathrm{g} / \mathrm{mL}$, respectively. The doses at $120 \%$ nominal concentration were obtained from aliquots of 1.2, 2.4 and $4.8 \mathrm{~mL}$ of the stock solution transferred into $25 \mathrm{~mL}$ volumetric flasks and diluted with phosphate buffer solution $\mathrm{pH} 7$ to give solutions with final concentrations of $19.2,38.4$ and $76.8 \mu \mathrm{g} / \mathrm{mL}$, respectively. These working solutions were assayed against the 3 concentration levels of the reference standard solution at $100 \%$ nominal concentration.

Selectivity - The ability of the proposed method to assess the content of CFTX sodium in the presence of impurities and degraded substances was tested by comparing the results obtained in the bioassay to the results from the pharmacopeial LC method for the identical degraded sample. A CFTX sodium commercial sample was reconstituted with water for injection and heated to $50^{\circ} \mathrm{C}$ for 2 days. The sample was analyzed by both methods at 0,24 and $48 \mathrm{~h}$. The conditions of the LC method were in accordance with the USP monograph for CFTX sodium (United States Pharmacopeia, 2011).

Robustness - Several method parameters were modified in assaying a CFTX sample. The considered factors were the inoculum concentration $(1.3 \%)$, incubation temperature $\left(32^{\circ} \mathrm{C}\right)$, volume of the inoculated layer (thickness $-4 \mathrm{~mL}$ ) and the solvent used for the standard and sample dilution (sterile water for injection).

\section{RESULTS AND DISCUSSION}

The use of a suitable analytical method is fundamental in the quality control of active substances in either the pharmaceutical or raw material form. The choice of the method is normally based on several factors such as the drug source; its complexity; purity and sample quantity; and the qualitative, semi-quantitative or quantitative purpose of the method. Furthermore, the availability of equipment and reagents should be considered in the development of accessible and useful methodologies.

Taking in account that the potency of an antibiotic may be assessed through the comparison of the inhibition of growth of a susceptible microorganism induced by known concentrations of the antibiotic and its respective reference standard (European Pharmacopoeia, 2005; United States Pharmacopeia, 2011), a 3 × 3 microbiological assay was proposed for determining the CFTX sodium concentration in injectable pharmaceutical dosage forms.

The range of the doses selected ( 16 to $64 \mu \mathrm{g} / \mathrm{mL}$ ) for the bioassay was shown to be most appropriate for this assay system for the following reasons: the susceptibility of the microorganism to lower concentrations on the curve, the linear relationship between the logarithm of the dose and the observed response, and the significant slope of the curve. The linearity study involved 12 independent assays with 
6 plates/assay. The experimental average zone diameters $(\mathrm{mm})$ and RSD values (\%) for the standard solutions are presented in Table I. The difference between the average size of the inhibition zones for doses $16-32 \mu \mathrm{g} / \mathrm{mL}$, and $32-64 \mu \mathrm{g} / \mathrm{mL}$ was approximately $3 \mathrm{~mm}$, showing good linearity in the response obtained by the method. Furthermore, the RSD values showed low variability in the response (intradose) obtained in this bioassay.

TABLE I - Mean diameters of the growth inhibition zones obtained for the CFTX standard curve for 16,32 and $64 \mu \mathrm{g} / \mathrm{mL}$ solutions

\begin{tabular}{ccc}
\hline $\begin{array}{c}\text { Concentration } \\
(\mu \mathrm{g} / \mathrm{mL})\end{array}$ & $\begin{array}{c}\text { Mean diameter } \pm \mathrm{SD}^{\mathrm{a}} \\
(\mathrm{mm})\end{array}$ & $\begin{array}{c}\mathrm{RSD} \\
(\%)\end{array}$ \\
\hline 16 & $16.3+/-0.3$ & 1.9 \\
32 & $19.4+/-0.2$ & 1.0 \\
64 & $22.4+/-0.5$ & 2.0 \\
\hline
\end{tabular}

${ }^{\mathrm{a}} \mathrm{n}=12$ independent assays with 6 Petri dishes each

The logarithm of the concentrations $(\mu \mathrm{g} / \mathrm{mL})$ and the mean diameter of the inhibition zones $(\mathrm{mm})$ were used to calculate the calibration curve for CFTX. The method showed good linearity for the range of $16-64 \mu \mathrm{g} / \mathrm{mL}$. The representative linear equation was $\mathrm{y}=10.176 \mathrm{x}+$ 4.046. The determination coefficient $\left(\mathrm{r}^{2}=0.99998\right)$ and correlation coefficient $(\mathrm{r}=0.99999)$ were highly significant. The bioassays were validated using an analysis of variance (ANOVA). In all experiments, the regression was highly significant $(\mathrm{P}<0.05)$ and no deviation was found in either the parallelism or the linearity $(\mathrm{P}>0.05)$. Moreover, all bioassays gave potency results within a confidence interval of $90-115 \%$ (IC95), indicating that the experiments performed during the validation were well executed. Simultaneously, the developed method was found to have significant response differentiation between doses and significant sensitivity to the selected doses.

The bioassay precision, in terms of repeatability (intra-assay), was evaluated by analyzing, on identical days, six different test solutions of CFTX sodium powder for injection with identical theoretical concentrations. The CFTX activity ranged from $99.2 \%$ to $102.8 \%$, with an RSD value of $1.4 \%$ (Table II).

To calculate the intermediate precision, the same sample was analyzed in triplicate on 2 separate days (between-day; Table III) and by 2 different analysts (between-analysts; Table IV), yielding RSD values of $2.1 \%$ and $2.5 \%$, respectively. These low RSD values confirmed the capacity of the method to generate, with the same sample, reproducible results with a low response variation in independent assays.
TABLE II - Results of the repeatability evaluation of the microbiological assay of CFTX powder for injection

\begin{tabular}{ccccc}
\hline $\begin{array}{c}\text { Theoretical } \\
\text { amount } \\
(\mathrm{mg} / \mathrm{fa})\end{array}$ & $\begin{array}{c}\text { Experimental } \\
\text { amount } \\
(\mathrm{mg} / \mathrm{fa})\end{array}$ & $\begin{array}{c}\text { Potency } \\
(\%)\end{array}$ & $\begin{array}{c}\text { Confidence } \\
\text { interval } \\
(\text { IC95) }\end{array}$ & $\begin{array}{c}\text { RSD } \\
(\%)\end{array}$ \\
\hline & 514.2 & 102.8 & $95.4-110.9$ & \\
& 496.2 & 99.2 & $93.1-105.8$ & \\
500 & 499.8 & 99.9 & $97.3-102.7$ & 1.4 \\
& 512.5 & 102.5 & $96.0-109.5$ & \\
& 502.5 & 100.5 & $91.9-109.9$ & \\
& 509.1 & 101.8 & $95.6-108.5$ & \\
\hline
\end{tabular}

fa - flask ampoule

TABLE III - Between-day precision data of the CFTX bioassay. Sample solutions at $100 \%$ theoretical concentration were tested in triplicate in two separate days

\begin{tabular}{cccc}
\hline Day & $\begin{array}{c}\text { Potency found } \\
(\%)\end{array}$ & $\begin{array}{c}\text { Confidence interval } \\
\text { (IC95) }\end{array}$ & $\begin{array}{c}\text { RSD } \\
(\%)\end{array}$ \\
\hline \multirow{2}{*}{1} & 100.5 & $91.9-109.9$ & \\
& 101.8 & $95.6-108.5$ & \\
& 102.8 & $95.4-110.9$ & \multirow{2}{*}{2.1} \\
2 & 102.8 & $93.0-113.8$ & \\
& 99.6 & $96.0-103.3$ & \\
\hline
\end{tabular}

TABLE IV - Between-analyst precision results obtained in the CFTX bioassay validation. Sample solutions at $100 \%$ theoretical concentration were tested in triplicate by two analysts

\begin{tabular}{lccc}
\hline Analyst & $\begin{array}{c}\text { Potency } \\
\text { found (\%) }\end{array}$ & $\begin{array}{c}\text { Confidence interval } \\
\text { (IC95) }\end{array}$ & RSD (\%) \\
\hline \multirow{2}{*}{1} & 99.6 & $96.0-103.3$ & \\
& 97.5 & $93.2-101.9$ & \\
\cline { 1 - 2 } 2 & 102.8 & $93.0-113.8$ & \multirow{2}{*}{2.5} \\
& 96.2 & $91.5-101.1$ & \\
& 97.1 & $91.9-102.5$ & \\
\hline
\end{tabular}

The accuracy of the method was evaluated at 80 , 100 and $120 \%$ of the range selected for the bioassay (16-64 $\mu \mathrm{g} / \mathrm{mL})$, covering the specific range of $12.8-76.8 \mu \mathrm{g} / \mathrm{mL}$. The mean accuracy was $100.5 \%$ with an RSD of $1.6 \%$ (Table V). Thus, the results obtained in the bioassay were close to the true concentration values of the tested samples. Moreover, it shows the capacity 
TABLE V - Accuracy of the proposed microbiological assay assessed by the analysis, in triplicate, of CFTX sample solutions diluted to $80 \%, 100 \%$ and $120 \%$ of the theoretical concentration

\begin{tabular}{|c|c|c|c|c|c|}
\hline Theoretical potency (\%) & Day & Potency found (\%) & Average potency (\%) & Accuracy $(\%)$ & $\mathrm{RSD}(\%)$ \\
\hline & 1 & 81.9 & & & \\
\hline \multirow[t]{3}{*}{80} & 2 & 81.5 & 81.8 & & \\
\hline & 3 & 81.9 & & & \\
\hline & 1 & 99.1 & & & \\
\hline \multirow[t]{3}{*}{100} & 2 & 99.3 & 99.0 & 100.5 & 1.6 \\
\hline & 3 & 98.5 & & & \\
\hline & 1 & 120.3 & & & \\
\hline \multirow[t]{2}{*}{120} & 2 & 120.1 & 120.4 & & \\
\hline & 3 & 120.7 & & & \\
\hline
\end{tabular}

of the proposed method to accurately quantify or detect samples containing low or high concentrations of CFTX, displaying that the bioassay is able to detect samples that do not meet the assay requirements recommended by the Pharmacopeias. Generally, this essential parameter for quantitative methods is not tested in agar diffusion assay validation studies.

To evaluate the selectivity of the proposed method, a CFTX commercial sample reconstituted to $10 \mathrm{mg} / \mathrm{mL}$ was exposed to dry heat $\left(50^{\circ} \mathrm{C}\right)$ for $48 \mathrm{~h}$. The concentration of the remaining CFTX in the sample was assessed by both the LC pharmacopeial method (United States Pharmacopeia, 2011) and the proposed bioassay at 0,24 and $48 \mathrm{~h}$. At time zero, the CFTX potency was $103.1 \% \pm 0.6$ and $107.3 \% \pm 0.6$ in the bioassay and HPLC, respectively. The CFTX showed low thermal stability, as shown in Figure 2, in which similar decreasing concentration curves were registered by both methods. However, the microbiological assay

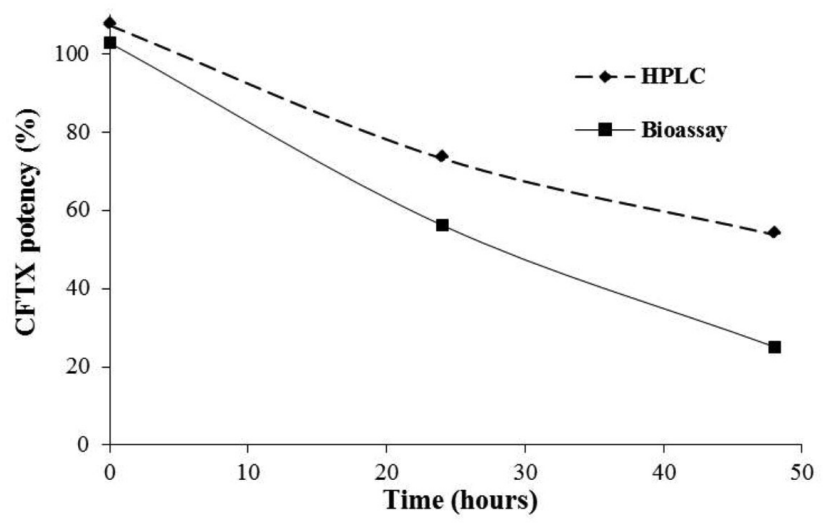

FIGURE 2 - Bioassay selectivity: the remaining content of CFTX at time 0,24 and $48 \mathrm{~h}$ of exposure to dry heat at $50^{\circ} \mathrm{C}$ as assessed by HPLC and the biological assay. presented higher sensitivity, because it showed a decrease in potency of approximately $77 \%$, as compared to $53 \%$ detected by HPLC for the same sample. This preliminary result shows that the decomposition products of CFTX were not microbiologically active. Therefore, the microbiological assay was shown to be specific, because the impurities and degradation products did not interfere in the ability of the method to assess the analyte.

Figure 3 displays the chromatograms of the CFTX sodium reference standard (A), the freshly prepared sample (B), and after $24 \mathrm{~h}$ (C) and $48 \mathrm{~h}$ (D) of exposure to dry heat at $50{ }^{\circ} \mathrm{C}$. The main peak at approximately $3.7 \mathrm{~min}$ corresponds to CFTX. In 3C and 3D, the secondary peaks increase, mainly at approximately $3.5 \mathrm{~min}$.

Considering the quantitation purpose of this bioassay and its inherent response variability that is characteristic of all bioassays systems (United States Pharmacopeia, 2011), it was considered essential to test the influence of small variations in the analytical conditions initially proposed. Among several critical factors involved in an agar diffusion assay, 4 were selected. These are directly related to the substance diffusibility and the growth of the inoculum. Therefore, to assess the method robustness, the following parameters were modified: inoculum concentration $(1.3 \%)$, incubation temperature $\left(32{ }^{\circ} \mathrm{C}\right)$, volume (thickness) of the inoculated layer $(4 \mathrm{~mL})$ and the solvent used for standard and sample dilution (bidistilled water) as shown in Table VI. The results showed no significant influence on the mean potencies when an ANOVA was applied $(\mathrm{P}<0.05)$, supporting the robustness of the method. The robustness results were also close to the range of $96.2 \%$ to $102.8 \%$ obtained under normal conditions for the repeatability, between-day/ analyst precision and accuracy at $100 \%$ of the nominal concentration. 

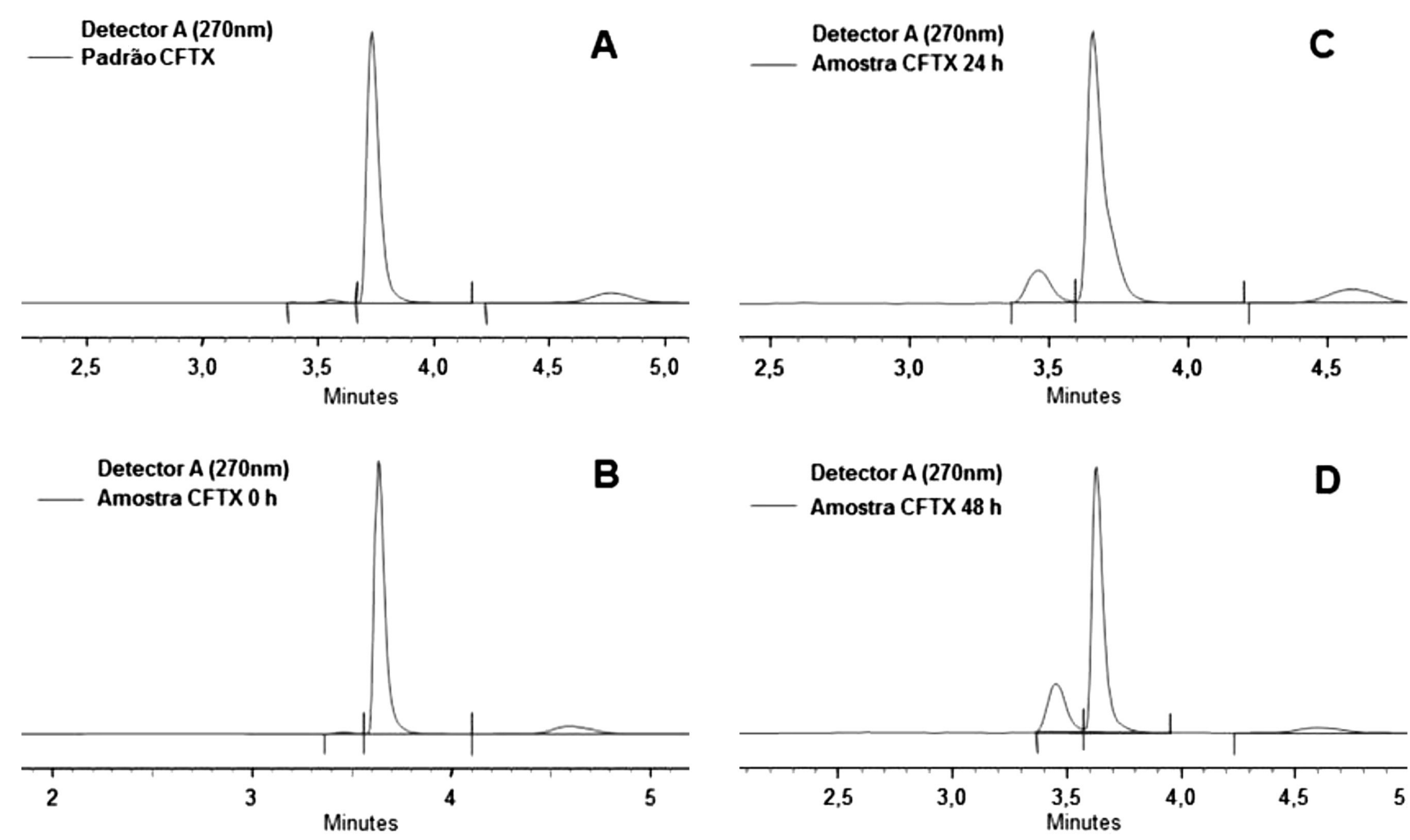

FIGURE 3 - Chromatograms of the CFTX reference standard (A). Freshly prepared sample (B). Sample after exposure to dry heat at $50{ }^{\circ} \mathrm{C}$ for $24 \mathrm{~h}(\mathrm{C})$ and $48 \mathrm{~h}(\mathrm{D})$. The CFTX main peak is at $3.7 \mathrm{~min}$. The chromatographic parameters were $\lambda=270-\mathrm{nm}$, $\mathrm{C} 18$ column and mobile phase (water, acetonitrile, buffer solution $\mathrm{pH} 7$, buffer solution $\mathrm{pH} 5-552: 400: 44: 4$ ) containing $0.32 \%$ of tetraheptylammonium bromide was used at a flow rate of $2 \mathrm{~mL} / \mathrm{min}$.

TABLE VI - Robustness data of the CFTX bioassay validation tested at $100 \%$ theoretical sample concentration

\begin{tabular}{|c|c|c|c|c|}
\hline Condition challenged & Parameter & Potency found $(\%)$ & Confidence interval (IC95) & RSD $(\%)$ \\
\hline \multirow[b]{2}{*}{ Inoculum concentration } & \multirow[b]{2}{*}{$1.3 \%$} & 99.3 & $93.7-105.4$ & \multirow{10}{*}{2.3} \\
\hline & & 99.2 & $94.2-104.6$ & \\
\hline \multirow{3}{*}{ Incubation temperature } & \multirow{3}{*}{$32^{\circ} \mathrm{C}$} & 101.0 & $94.3-108.2$ & \\
\hline & & 102.7 & $96.3-109.6$ & \\
\hline & & 102.7 & $95.2-110.8$ & \\
\hline \multirow[t]{2}{*}{ Inoculated layer } & \multirow[t]{2}{*}{$4 \mathrm{ml}$} & 101.2 & $92.8-110.4$ & \\
\hline & & 101.4 & $97.1-105.8$ & \\
\hline \multirow{3}{*}{ Standard/sample solvent } & \multirow{3}{*}{ Bidistilled water } & 95.4 & $86.1-105.5$ & \\
\hline & & 98.9 & $89.9-108.8$ & \\
\hline & & 99.5 & $90.6-109.2$ & \\
\hline
\end{tabular}

\section{CONCLUSION}

Analytical methods used for the quantitative determination of active substances must generate reproducible and reliable data. Therefore, in the routine quality control of medicine, it is mandatory to use well- characterized and fully validated analytical methods to yield reliable results that can be satisfactorily interpreted. The proposed microbiological assay for determining the potency of CFTX in pharmaceutical formulations was fully validated according to the $\mathrm{ICH}$ parameters and produced results which confirm its specificity, accuracy, robustness, 
precision and significant linearity of response. Moreover, the bioassay produced results supporting those obtained by the pharmacopeial LC method for CFTX. However, the biological method has several advantages, including its simplicity and low cost, becoming increasingly appropriate when a LC system is not available for determining the potency of the antibiotic. Therefore, the proposed bioassay can be a useful method in the quality control of ceftriaxone sodium in pharmaceutical products and the raw material.

\section{REFERENCES}

ADEGOKE, O.A.; QUADRI, M.O. Novel spectrophotometric determinations of some cephalosporins following azo dye formation with $p$-dimethylaminobenzaldehyde. Arab. J. Chem., 2012. Available at: <http://www.sciencedirect.com/ science/article/pii/S1878535212000329>. Accessed on: 20 Feb. 2012.

AHMED, S.M.A.; ELBASHIR, A.A.; ABOUL-ENEIN, H.I. New spectrophotometric method for determination of cephalosporins in pharmaceutical formulations. Arab. $J$. Chem., 2011. Available at: http://dx.doi.org/10.1016/j. arabjc.2011.08.012 Accessed on: 20 Feb. 2012.

AKL, M.A.; AHMED, M.A.; RAMADAN, A. Validation of an HPLC-UV method for the determination of ceftriaxone sodium residues on stainless steel surface of pharmaceutical manufacturing equipments. J. Pharm. Biomed. Anal., v.55, n.2, p.247-252, 2011.

AL-MOMANI, I.F. Spectrophotometric determination of selected cephalosporins in drug formulations using flow injection analysis. J. Pharm. Biomed. Anal., v.25, n.5-6, p.751-757, 2001.

AMIN, A.S.; RAGABB, G.H. Spectrophotometric determination of certain cephalosporins in pure form and in pharmaceutical formulations. Spectrochim. Acta A. Mol. Biomol. Spectrosc., v.60, n.12, p.2831-2835, 2004.

ASCALONE, V.; DAL BÒ, L. Determination of ceftriaxone, a novel cephalosporin, in plasma, urine and saliva by high performance liquid chromatography on a NH2-bondedphase column. J. Chromatogr., v.273, n.2, p.357-366, 1983.

BAUMGARTNER, J.D.; GLAUSER, M.P. Pharmacokinetic and microbial susceptibility studies of ceftriaxone. Eur. $J$. Clin. Microbiol., v.2, n.5, p.501-504, 1983.
BESKID, G.; CHRISTENSON, J.G.; CLEELAND, R.; DELORENZO, W.; TROWN, P.W. In vivo activity of ceftriaxone (Ro 13-9904), a new broad-spectrum semisynthetic cephalosporin. Antimicrob. Agents Chemother, v.20, n.2, p.159-167, 1981.

BOMPADRE, S.; FERRANTE, L.; LEONE, L. On-line solidphase extraction of cephalosporins. J. Chromatogr. A, v.812, n.6, p.191-196, 1998.

BOWMAN, D.B.; ARAVIND, M.K.; MICELI, J.N.; KAUFFMAN, R.E. Reversed-phase high-performance liquid-chromatographic method to determine ceftriaxone in biological fluids. J. Chromatogr., v.309, n.1, p.209-213, 1984.

BRITISH PHARMACOPOEIA. London: Her majesty's stationery office, $2009.3841 \mathrm{p}$.

CANTÓN, E.; ESTEBAN, M.J.; RIUS, F. Factors affecting the stability of ceftriaxone sodium in solution on storage. Int. J. Pharm., v.92, n.1-3, p.47-53, 1993.

CHAN-C., Y.; CHAN, K.; FRENCH, G.L. Rapid high performance liquid chromatographic assay of cephalosporins in biological fluids. J. Antimicrob. Chemother, v.18, n.4, p.537-545, 1986.

DIAS, C.A.G.; KADER, I.A.; AZEVEDO, P.; SUPERTI, S.; ALVES, D.; OLM, G. Agar diffusion tests with cefuroxime disks for predicting ceftriaxone susceptibility among isolates of streptococcus pneumoniae. Rev. Microbiol., v.29, n.4, p.314-316, 1998.

EICKHOFF, T.C.; EHRET, J. Comparative in vitro studies of Ro 13-9904, a new cephalosporin derivative. Antimicrob. Agents Chemother., v.19, n.3, p.435-442, 1981.

EL-WALILY, A.F.M.; GAZY, A.A.; BELAL, S.F.; KHAMIS, E.F. Quantitative determination of some thiazole cephalosporins through complexation with palladium (II) chloride. J. Pharm. Biomed. Anal., v.22, n.2, p.385-392, 2000.

EMMERSON, A.M.; LAMPORT, P.A.; REEVES, D.S.; BYWATER, M.J.; HOLT, H.A.; WISER, R.; ANDREWS, J.; HALL, M.J. Ceftriaxone: a three centre comparative in vitro susceptibility study. Eur. J. Clin. Microbiol., v.4, n.2, p.142-143, 1985. 
ERIC-JOVANOVIC, S.; AGBABA, D.; ZIVANOVSTAKIC, D.; VLADIMIROV, S. HPTLC determination of ceftriaxone, cefixime and cefotaxime in dosage forms. $J$. Pharm. Biomed. Anal., v.18, n.4-5, p.893-898, 1998.

ESTEBAN, M.J.; CANTÓN, E.; RIUS, F. Influence of temperature on degradation kinetic of Ceftriaxone in diluted and undiluted human serum. Antimicrob. Agents Chemother, v.34, n.6, p.1268-1270, 1990.

EUROPEAN PHARMACOPOEIA. 5.ed. European directorate for the quality of medicines. Strasbourg, 2005. 3086 p.

FARMACOPÉIA BRASILEIRA. 5.ed. Brasília: Agência nacional de vigilância sanitária, 2010. Available at: $<$ http:// www.anvisa.gov.br>. Accessed on: 14 June 2012.

GRANICH, G.G.; KROGSTAD, D.J. Ion pair highperformance liquid chromatographic assay for ceftriaxone. Antimicrob. Agents Chemother, v.31, n.3, p.385-388, 1987.

HECQ, J.D.; EVRARD, J.M.; VANBECKBERGEN, D.F.; JAMART, J.; GALANTI, L.M. Effect of freezing, long term storage and microwave thawing on the stability of ceftriaxone sodium in $5 \%$ dextrose infusion polyolefin bags at 2-8 ${ }^{\circ}$ C. Eur. J. Hosp. Pharm. Sci., v.12, n.3, p.52-56, 2006.

HEWITT, W. Microbiological assay for pharmaceutical analysis: a rational approach. Boca Raton: CRC Press, Interpharm, 2003. 260 p.

ICH Harmonised tripartite guideline. Validation of analytical procedures: text and methodology - Q2(R1) - ICH steering committee. Commission of the european communities, Geneva, 2005. Available at: <http://www.ich.org/LOB/ media/MEDIA417.pdf.>. Accessed on: 01 June 2012.

ISMAIL, M.M. Pharmacokinetics, urinary and mammary excretion of ceftriaxone in lactating goats. J. Vet. Med. A Physiol. Pathol. Clin. Med., v.52, n.7, p.354-358, 2005.

JANE, J.; SUBRAHMANYAN, E.V.S.; SATHANARAYANA, D. HPLC analysis of ceftriaxone and ceftizoxime. Asian J. Chem., v.18, n.4, p.3207-3209, 2006.

JAPANESE Pharmacopoeia. 15.ed. Tokyo: Yakuji Nippo LTD, 2006. 1788 p.
KOHLEPP, S.J.; GILBERT, D.N.; LEGGETT, J.E. Influence of assay methodology on the measurement of free serum ceftriaxone concentrations. Antimicrob. Agents Chemother, v.42, n.9, p.2259-2261, 1998.

MCWHINNEY, B.C.; WALLIS, S.C.; HILLISTER, T.; ROBERTS, J.A.; LIPMAN, J.; UNGERER, J.P.J. Analysis of 12 beta-lactam antibiotics in human plasma by HPLC with ultraviolet detection. J. Chromatogr. B Analyt. Technol. Biomed. Life Sci., v.878, n.22, p.2039-2043, 2010.

NEMUTLU, E.; KIR, S.; KATLAN, D.; BEKSAÇ, M.S. Simultaneous multiresponse optimization of an HPLC method to separate seven cephalosporins in plasma and amniotic fluid: application to validation and quantification of cefepime, cefixime and cefoperazone. Talanta, v.80, n.1, p.117-126, 2009.

NEU, H.C.; MEROPOL, N.J.; KWUNG, P.F. Antibacterial activity of Ceftriaxone (Ro 13.9904), a betalactamase stable cephalosporin. Antimicrob. Agents Chemother, v.19, n.3, p.414-423, 1981.

OKOYE, N.N.; NWOKEDI, G.I.C.; UKWUEZE, N.N.; OKOYE, F.B.C. Spectrophotometric determination of some cephalosporin antibiotics using Prussian blue reaction. Sci. Res. Essays, v.2, n.8, p.342-347, 2007.

OMAR, M.A.; ABDELMAGEED, O.H.; ATTIA, T.Z. Kinetic spectrofluorimetric determination of certain cephalosporins in human plasma. Talanta, v.77, n.4, p.1394-1404, 2009.

PATEL, I.H.; CHEN, S.; PARSONNET, M.; HACKMAN, M.R.; BROOKS, M.A.; KONIKOFF, J.; KAPLAN, S.A. Pharmacokinetics of ceftriaxone in humans. Antimicrob. Agents Chemother., v.20, n.5, p.634-641, 1981.

QUAGLIA, M.G.; BOSSI, E.; DELL'AQUILA, C.; GUIDOTTI, M. Determination of the binding of a fl2-blocker drug, furosemide and ceftriaxone to serum proteins by capillary zone electrophoresis. J. Pharm. Biomed. Anal., v.15, n.8, p.1033-1039, 1997.

REBUELTO, M.; ALBARELLOS, G.; AMBROS, L.; KREIL, V.; MONTOYA, L.; BONAFINE, R.; OTERO, P.; HALLU, R. Pharmacokinetics of ceftriaxone administered by the intravenous, intramuscular or subcutaneous routes to dogs. J. Vet. Pharmacol. Ther, v.25, n.1, p.73-76, 2002. 
SANKAR, D.G.; SUJATHA, N.; KUMAR, B.A.; MADHAVILATHA, P.V. UV-spectrophotometric determination of valacicyclovir and ceftriaxone. Asian J. Chem., v.18, n.4, p.3244-3246, 2006.

SENGÜN, F.I.; ULAS, K.; FEDAI, I. Analytical investigations of cephalosporins - II. Polarographic behaviour of ceftriaxone, cefuroxime, cefotaxime and ceftizoxime and assay of their formulations. J. Pharm. Biomed. Anal., v.3, n.2, p.191-199, 1985.

SCHMIDT, C.A.; AGARRAYUA, D.A.; LAPORTA, L.V.; MACHADO, J.C.; MANFIO, M.L.; BITTENCOURT, C.F. Development and validation of a microbiological agar assay for determination of cefuroxime sodium in pharmaceutical preparations. J. Microbiol. Methods, v.77, n.3, p.308-315, 2009.

SCHMIDT, C.A.; CARAZZO, M.; LAPORTA, L.; BITTENCOURT, C.F.; SANTOS, M.R.; FRIEDRICH, M. Development and validation of an agar diffusion assay for determination of ceftazidime in pharmaceutical preparations. J. AOAC Int., v.91, n.1, p.59-66, 2008.

SHAH, J.; JAN, M.R.; SHAH, S.; NAEEM, M. Spectrofluorimetric protocol for ceftriaxone in commercial formulation and human plasma after condensation with formaldehyde and ethyl acetoacetate. J. Fluoresc., v.21, n.6, p.2155-2163, 2011.

SOUZA, M.J.; KULMANN, R.R.; SILVA, L.M.; NOGUEIRA, D.R.; ZIMMERMANN, E.S.; SCHMIDT, C.A. Development and in-house validation of a microbiological assay for determination of cefepime in injectable preparations. J. AOAC Int., v.89, n.5, p.1367-1372, 2006.
STOECKEL, K. Pharmacokinetics of rocephin, a highly active new cephalosporin with an exceptionally long biological half-life. Chemotherapy, v.27, n.1, p.42-46, 1981.

TIPPA, D.M.R.; SINGH, N. Reconstitution stability of ceftriaxone sodium for injection in intravenous diluents. Pharm. Sinica, v.1, n.2, p.24-30, 2010.

TRAUTMANN, K.H.; HAEFELFINGER, P. Determination of the cephalosporin ro 13-9904 in plasma, urine, and bile by means of ion-pair reversed-phase chromatography. J. High Resolut. Chromatogr., v.4, n.2, p.54-59, 1981.

TSAI, T.H.; CHENG, F.C.; HUNG, L.C.; CHEN, C.F. Determination of unbound ceftriaxone in rat blood by online microdialysis and microbore liquid chromatography. Int. J. Pharm., v.193, n.1, p.21-26, 1999.

UNITED States Pharmacopeia 34 NF 29. Rockville: The United States Pharmacopeial Convention,2011.

YINHUAN, L.I.; JIURU, L.U. Chemiluminescence flowinjection analysis of $\beta$-lactam antibiotics using the luminolpermanganate reaction. Luminescence, v.21, n.4, p.251-255, 2006.

Received for publication on $17^{\text {th }}$ November 2012 Accepted for publication on $08^{\text {th }}$ July 2013 